University of Nebraska - Lincoln

DigitalCommons@University of Nebraska - Lincoln

USDA National Wildlife Research Center - Staff Publications
U.S. Department of Agriculture: Animal and Plant Health Inspection Service

2014

\title{
European starling feeding activity on repellent treated crops and pellets
}

\author{
Shelagh K. Tupper \\ United States Department of Agriculture, Animal and Plant Health Inspection Service, \\ shelagh.t.deliberto@usda.gov \\ Scott J. Werner \\ United States Department of Agriculture, Animal and Plant Health Inspection Service, \\ scott.j.werner@aphis.usda.gov \\ James C. Carlson \\ USDA/APHIS/WS National Wildlife Research Center, james.c.carlson@aphis.usda.gov \\ Susan E. Pettit \\ United States Department of Agriculture, Animal and Plant Health Inspection Service \\ John C. Wise \\ Michigan State University
}

See next page for additional authors

Follow this and additional works at: https://digitalcommons.unl.edu/icwdm_usdanwrc

Part of the Life Sciences Commons

Tupper, Shelagh K.; Werner, Scott J.; Carlson, James C.; Pettit, Susan E.; Wise, John C.; Lindell, Catherine A.; and Linz, George M., "European starling feeding activity on repellent treated crops and pellets" (2014). USDA National Wildlife Research Center - Staff Publications. 1571.

https://digitalcommons.unl.edu/icwdm_usdanwrc/1571

This Article is brought to you for free and open access by the U.S. Department of Agriculture: Animal and Plant Health Inspection Service at DigitalCommons@University of Nebraska - Lincoln. It has been accepted for inclusion in USDA National Wildlife Research Center - Staff Publications by an authorized administrator of DigitalCommons@University of Nebraska - Lincoln. 


\section{Authors}

Shelagh K. Tupper, Scott J. Werner, James C. Carlson, Susan E. Pettit, John C. Wise, Catherine A. Lindell, and George M. Linz 


\title{
European starling feeding activity on repellent treated crops and pellets
}

\author{
Shelagh K. Tupper ${ }^{\mathrm{a}, *}$, Scott J. Werner ${ }^{\mathrm{a}}$, James C. Carlson ${ }^{\mathrm{a}}$, Susan E. Pettit ${ }^{\mathrm{a}}$, John C. Wise ${ }^{\mathrm{b}}$, \\ Catherine A. Lindell ${ }^{c}$, George M. Linz ${ }^{d}$ \\ ${ }^{a}$ United States Department of Agriculture, Animal and Plant Health Inspection Service, Wildlife Services, National Wildife Research Center, \\ 4101 LaPorte Avenue, Fort Collins, CO 80521, USA \\ ${ }^{\mathrm{b}}$ Department of Entomology, Michigan State University, 206 CIPS, East Lansing, MI 48824, USA \\ ${ }^{\mathrm{c}}$ Department of Zoology, Michigan State University, 278 Giltner, East Lansing, MI 48824, USA \\ ${ }^{\mathrm{d}}$ United States Department of Agriculture, Animal and Plant Health Inspection Service, Wildlife Services, National Wildlife Research Center, \\ 2110 Miriam Circle, Suite B, Bismarck, ND 58501, USA
}

\section{A R T I C L E I N F O}

\section{Article history:}

Received 26 November 2013

Received in revised form

23 April 2014

Accepted 2 May 2014

\section{Keywords}

Anthraquinone

Sturnus vulgaris

SucraShield

Sucrose octanoate ester

\begin{abstract}
A B S T R A C T
The varied diet of European starlings (Sturnus vulgaris L.) can present challenges when working with starlings in experimental testing and holding situations and should be taken into account when testing repellents applied to food. Our purpose was to evaluate an anthraquinone-based repellent (Arkion Life Sciences, New Castle, DE, USA; active ingredient 50\% 9,10-anthraquinone; hereafter anthraquinone) and SucraShield ${ }^{\mathrm{TM}}$ (Natural Forces, Davidson, NC, USA; active ingredient 40\% sucrose octanoate esters) repellent for non-lethal protection of specialty crops (i.e., fruit, sweet corn) and grains. Our objectives were to evaluate (1) laboratory efficacy of anthraquinone applied topically to blueberries and sweet corn, (2) laboratory efficacy of anthraquinone applied to two pellet matrices, and (3) laboratory efficacy of SucraShield ${ }^{\mathrm{TM}}$ as a chemical repellent for European starlings. We found that anthraquinone was not an effective repellent for blueberries or sweet corn, although consumption of each matrix varied potentially due to sucrose content. Anthraquinone was an effective repellent on CU Bird Carrier pellets with $6275 \mathrm{ppm}$ needed to achieve $80 \%$ repellency, whereas up to 35,000 ppm anthraquinone was not effective when the anthraquinone was not topically applied. SucraShield was not an effective repellent for starlings and in fact increased consumption of CU Bird Carrier as concentration increased.
\end{abstract}

Published by Elsevier Ltd.

\section{Introduction}

While some animals including birds of prey and tropical frugivores (Meserve, 1977) are able to maintain a relatively constant diet throughout the year, many species utilize more plastic food consumption strategies. The European starling (Sturnus vulgaris L.) is one example of a species whose diet changes widely throughout the year. Gut contents of European starlings show that they consume a variety of plant (e.g. seed and fruit) and animal (e.g. earthworm, snail, insect) species in varying ratios depending on season (Taitt, 1973; Feare, 1984; Fischl and Caccamise, 1987). Authors attribute the European starlings' ability to thrive in so many varied habitats to this ability to change their diet to accommodate what is locally available (Taitt, 1973).

\footnotetext{
* Corresponding author. Tel.: +1970 2666121.

E-mail address: shelagh.k.tupper@aphis.usda.gov (S.K. Tupper).
}

European starlings are known for taking advantage of these flexible feeding habits to thrive in areas where birds with a more specialized diet cannot. This has made European starlings well suited to cause damage to agriculture crops and feed lots in the U.S., Europe and Australia (Stickley et al., 1976; Dolbeer et al., 1978; Wright, 1982; Mason et al., 1985; Summers, 1985; Glahn and Otis, 1986; Feare, 1992; Bentz et al., 2007), and damage can be extensive when starlings congregate in large foraging flocks (Shwiff et al., 2012). Bird damage to blueberry crops from species including European starlings, American robin (Turdus migratorius L.) and common grackle (Quiscalus quiscula L.) in 1989 were estimated at $\$ 8.5$ million based on survey results (Avery et al., 1992). Starlings are also known to damage sweet corn and in cage trials consumed $40 \%$ more sweet corn than red-winged blackbirds (Agelaius phoeniceus L.; Woronecki et al., 1988). Repellent-based methods to reduce economic damage from starlings to crop and livestock production have been evaluated, but most are not considered economically effective against starlings (Avery, 1992). Anthraquinone-based 
products used as seed treatments have been successfully tested with several species of birds including Canada geese (Branta canadensis L.), sandhill cranes (Grus canadensis L.), red-winged blackbirds, and common grackles (Blackwell et al., 2001; Werner et al., 2009, 2011a,b). Limited testing with European starlings was conducted by Poche (1998) which showed that starlings detect anthraquinone at $150 \mathrm{ppm}$ on grain baits but higher doses were required to achieve repellency. Anthraquinone has been shown to cause post-ingestional distress in birds that often leads to vomiting (Avery et al., 1997). SucraShield ${ }^{\mathrm{TM}}$ (Natural Forces, Davidson, NC, USA; active ingredient $40 \%$ sucrose octanoate esters) is marketed as a sugar-based insecticide and has not been previously evaluated for avian repellency. However, sugars specifically sucrose sugars are known to repel certain species of birds including European starlings (Martinez del Rio et al., 1988 Martinez del Rio, 1990).

Although in Europe there has been a recent population decline of European (common) starling populations, and they have been listed as a species of highest conservation concern (Freeman et al., 2007; Eglington and Pearce-Higgins, 2012), they still flock and cause damage in agriculture crops and feed lots due to their gregarious nature. An improved understanding of starling behavior and effective means to present repellents to starlings will benefit agricultural producers and the avian community. Our purpose was to evaluate an anthraquinone-based repellent (Arkion Life Sciences, New Castle, DE, USA; active ingredient 50\% 9,10-anthraquinone; hereafter anthraquinone) and SucraShield for non-lethal protection of specialty crops (i.e., fruit, sweet corn) and grains. Our objectives were to evaluate (1) laboratory efficacy of anthraquinone applied topically to blueberries and sweet corn, (2) laboratory efficacy of anthraquinone applied to two pellet matrices, and (3) laboratory efficacy of SucraShield as a chemical repellent for European starlings. The capture, care, and use of all birds associated with our repellent efficacy studies were approved by the Animal Care and Use Committee of the United States Department of Agriculture's (USDA) National Wildlife Research Center (NWRC Studies QA-1740, 1901, S.J. Werner-Study Director, QA-1748, J.C. Carlson-Study Director).

\section{Methods}

\subsection{Facilities, maintenance and diets}

European starling feeding experiments were conducted at the USDA, NWRC in Fort Collins, CO, USA. In total, we used 301 European starlings for laboratory efficacy and preference experiments. We provided water ad libitum to all birds throughout testing and maintained all starlings in $4.9 \times 2.4 \times 2.4$-m cages $(40-50$ birds/ cage) within a wire mesh-sided building for $\geq 2$ weeks prior to our experiments (i.e., for quarantine, holding). Starling experiments were conducted in individual cages $(0.9 \times 1.8 \times 0.9 \mathrm{~m})$ within a wire mesh-sided building. We provided all birds free access to grit and maintenance diet during quarantine and holding. The maintenance diet consisted of Layena ${ }^{\circledR}$ poultry pellets (Purina Mills, St. Louis Mo, USA).

\subsection{Feeding experiments}

Between April 2010 and December 2012, we conducted four laboratory efficacy experiments to establish concentrationresponse relationships for European starlings offered blueberries, sweet corn, 16\% Poultry Layer Complete (Ranch-Way Feeds, Fort Collins, CO, USA), and CU Bird Carrier (CUBC, Purina Mills, Gray Summit, MO, USA) treated with anthraquinone. We conducted one laboratory efficacy experiment to establish a concentrationresponse relationship for European starlings offered CUBC treated with SucraShield ${ }^{\mathrm{TM}}$ (Table 1). Our laboratory efficacy experiments included concentration-response experiments and preference experiments (Table 1). All starlings acclimated within individual cages for five days (Wednesday-Sunday) prior to each of the feeding experiments.

\subsubsection{Concentration response}

Subsequent to the acclimation period, concentration-response experiments included a 3-day pre-test (untreated food; MondayWednesday) and a 1-day test (repellent-treated food; Thursday). Concentration levels were selected based on a combination of the end-use formulation proposed by the company and maximum levels that we were able to apply to test diets and still have the potential to meet residue requirements for ripening crops (i.e. blueberry and sweet corn). Food consumption ( $\pm 0.1 \mathrm{~g})$ was measured the day subsequent to each of the pre-test and test days of each experiment. We conducted residue analyses of the 16\% Poultry Layer Complete, and CUBC anthraquinone treatments (Table 1).

During the acclimation period, one food bowl that held untreated food ( 20 blueberries, $75 \mathrm{~g}$ of $16 \%$ poultry pellets, or $75 \mathrm{~g}$ CUBC) was presented on the north side of the cage at 0800 , daily. Starlings were only offered untreated blueberries from 8 to noon and were subsequently offered maintenance diet (ad libitum) after $4 \mathrm{~h}$. During the pre-test, one bowl of untreated food was presented on the north side of the cage. Starlings were only offered untreated blueberries from 8 to noon and were subsequently offered maintenance diet (ad libitum) after $4 \mathrm{~h}$. Birds were ranked based upon pre-test consumption of untreated food and assigned to treatment groups such that each group was similarly populated with birds that exhibited high-low daily consumption. We then randomly

Table 1

Summary of European starling (Sturnus vulgaris) testing at the National Wildlife Research Center, Fort Collins, Colorado, USA.

\begin{tabular}{|c|c|c|c|c|c|c|}
\hline Commodity & Repellent tested & Test type & $\begin{array}{l}\text { Number of } \\
\text { treatment } \\
\text { groups }\end{array}$ & Concentrations tested & Residues (ppm) & $\begin{array}{l}(n) \text { per } \\
\text { treatment }\end{array}$ \\
\hline Blueberry & Anthraquinone & Concentration response & 5 & $0.1 \%, 0.2 \%, 0.3 \%, 0.4 \%, 0.5 \%$ & $\mathrm{n} / \mathrm{a}$ & 10 \\
\hline Blueberry & Anthraquinone & Preference & 1 & $0.3 \%$ & $\mathrm{n} / \mathrm{a}$ & 10 \\
\hline Sweet corn & Anthraquinone & $\begin{array}{l}\text { Concentration response/ } \\
\text { preference }\end{array}$ & 6 & $0.1 \%, 0.25 \%, 0.5 \%, 0.75 \%, 1.0 \%, 2.0 \%$ & $327,429,700,1574,2770,4805$ & 11 \\
\hline 16\% Poultry Pellets & Anthraquinone & Concentration response & 6 & $0.25 \%, 0.5 \%, 1.0 \%, 2.0 \%, 3.0 \%$ and $4.0 \%$ & $\begin{array}{l}1920,3580,7870,14,800,23,300 \text {, } \\
35,000\end{array}$ & 9 \\
\hline $16 \%$ Poultry pellets & Anthraquinone & Preference & 1 & $0.25 \%$ & 1920 & 11 \\
\hline CUBC & Anthraquinone & Concentration response & 4 & $0.5 \%, 1.0 \%, 2.0 \%, 4.0 \%$ & $5130,10,100,20,500,33,300$ & 11 \\
\hline CUBC & SucraShield & Concentration response & 5 & $0.25 \%, 0.5 \%, 0.75 \%, 1.0 \%, 2.0 \%$ & $\mathrm{n} / \mathrm{a}$ & 11 \\
\hline CUBC & SucraShield & Preference & 1 & $1.0 \%$ & $\mathrm{n} / \mathrm{a}$ & 11 \\
\hline
\end{tabular}


assigned repellent treatments among groups (Table 1). During the 1-day ( $4 \mathrm{~h}$ for blueberries) test, one bowl of treated food was presented on the north side of the cage.

\subsubsection{Preference testing}

Preference experiments included a 4-day test (MondayThursday) of treated versus untreated food. The north-south placement of treated and untreated food was randomized on the first day and alternated on subsequent days of preference experiments. Food consumption $( \pm 0.1 \mathrm{~g})$ was measured the day subsequent (after $4 \mathrm{~h}$ test for blueberries) to each of the test days of each experiment. We conducted residue analyses of the $16 \%$ Poultry Layer Complete, and CUBC anthraquinone treatments (Table 1).

During the acclimation period, each experimentally-naïve starling was offered two food bowls that contained untreated or treated food ( 20 blueberries, $75 \mathrm{~g}$ of $16 \%$ poultry pellets, or $75 \mathrm{~g}$ CUBC) presented on the north and south sides of the cage daily. Starlings were only offered blueberries from 8 to noon and subsequently offered maintenance diet (ad libitum) after $4 \mathrm{~h}$. One food bowl contained treated food; the remaining food bowl contained untreated food.

\subsubsection{Concentration response/preference testing (sweet corn)}

During the acclimation period, one food bowl that contained $75 \mathrm{~g}$ of unadulterated maintenance diet (Layena ${ }^{\circledR}$ poultry pellets) was presented on the north side of the cage at 0800 , daily. We ranked starlings (experimentally-naïve; $n=66$ ) based upon average pretreatment consumption of poultry pellets and assigned them to one of six treatment groups ( $n=11$ birds/group). We then randomly assigned one of the six anthraquinone concentrations to each group. Birds in treatment groups 1-6 received two ears of corn, one treated, and one untreated during each day of the 4-day test. Ears of corn, with husks intact, were placed vertically on wooden stands within cages. We collected a $20 \mathrm{~g}$ sample of husk and kernels from ears of corn used in our experiments to be analyzed for anthraquinone residues ( $\pm 1 \mathrm{ppm}$ anthraquinone).

We used two criteria to measure corn damage. First, we estimated percent damage using methods reported by Klosterman et al. (2013). Length and the circumference of each ear of corn were measured: circumference was measured at the center point of the ear. We then measured the length and width of the area from which kernels were removed from the ear of corn. Percent damage was calculated as: Percent $(\%)=$ Damage (length*width)/Ear (length*circumference). Second, we used a binary measurement (presence/absence) to assess overall damage to sweet corn. If ears showed signs of husk slitting or kernel consumption the ear was recorded as "damaged". If no damage to the husk and kernels were observed the ear was recorded as "not damaged". We conducted two separate analyses because sweet corn growers will need a repellent that prevents birds from damaging ears while field corn producers will need a repellent that reduces corn consumption. Thus, it was important for us to demonstrate that anthraquinone can reduce both the percent of corn consumed and the number of ears affected (Carlson et al., 2013).

\subsection{Test formulations}

\subsubsection{Blueberries}

We formulated blueberry treatments by applying aqueous suspensions of anthraquinone ( $60 \mathrm{~mL}$ suspension/ $\mathrm{kg}$ blueberry) to fresh blueberries using a dunking method. Each morning of testing we immersed each birds individual set of 20 blueberries (35-40 g) in a vortexed aqueous suspension of anthraquinone $(60 \mathrm{~mL}$ suspension/kg blueberries) for $10 \mathrm{~s}$ each. Blueberries were then placed on a $2.0 \mathrm{~cm} \times 2.0 \mathrm{~cm}$ mesh screen to dry and placed into the bowl to be offered to starlings.

\subsubsection{Sweet corn}

We formulated sweet corn treatments for our laboratory efficacy experiments by applying aqueous suspensions of anthraquinone (11.4 L/10 ears corn) to ripening sweet corn using a dunking method. Ears of corn had been hand harvested from fields when they were at full milk stage. Anthraquinone was mixed with tap water to produce 6 different, $0.01 \mathrm{~m}^{3}$ concentrations of anthraquinone by volume $(0.1 \%, 0.25 \%, 0.5 \%, 0.75 \%, 1 \%$, and $2 \%)$. All anthraquinone concentrations were stored in $18.9 \mathrm{~L}$ buckets at room temperature. Anthraquinone concentrations were mixed by hand for 5 min each day before treating corn. Each ear was treated with anthraquinone by immersing it in its designated bucket of anthraquinone for $2 \mathrm{~s}$. Ears were then hung overnight in nylon mesh bags to dry. Husks were not removed from ears prior to repellent testing.

\subsubsection{6\% Poultry Layer Complete}

Due to the absorbent nature of the manufactured $16 \%$ poultry pellets used as the starling maintenance diet we were unable to apply the liquid formulation of anthraquinone to the manufactured 16\% Poultry Layer Complete pellets (RanchWay Feeds, Fort Collins, Colorado, USA). Thus, we formulated test pellet treatments by incorporating technical anthraquinone (Arkion Life Sciences, New Castle, DE, USA; 99\% 9,10-anthraquinone) into ground 16\% Poultry Layer Complete pellets and then pelletized the mixture using a California Pellet Mill (CPM, Crawfordsville, Indiana, USA) into pellets the same length and diameter as the original pellet.

\subsection{4. $C U$ Bird carrier}

We formulated CUBC treatments for our laboratory efficacy experiments by applying aqueous suspensions of anthraquinone or SucraShield ${ }^{\mathrm{TM}}$ ( $60 \mathrm{~mL}$ suspension/kg CUBC) to CUBC using a rotating mixer and household spray equipment.

\subsection{Data analysis}

We hypothesized that repellency would be directly related to repellent concentration during our concentration-response experiments. We previously established $\geq 80 \%$ repellency as efficacious during our laboratory feeding experiments (Werner et al., 2009, 2010, 2011a,b). Thus, we predicted that consumption of efficacious treatments (i.e., threshold repellency) would be $<20 \%$ of pretreatment consumption during the starling concentration-response experiments. The dependent measure of our concentration-response experiments was calculated as test consumption of treated test diet relative to average pretreatment consumption of untreated test diet (i.e., percent repellency). We determined normality by examining the studentized residuals and the normal quantile plots within Proc Univariate (SAS v9.2). We used linear regression procedures (SAS v9.2) to analyze repellency as a function of anthraquinone concentration (ppm).

The dependent measure for our preference experiments was average (i.e., daily) test consumption of treated and untreated test diet. We determined normality by examining the studentized residuals and the normal quantile plots within Proc Univariate (SAS v9.2). Consumption data for each experiment were subjected to a repeated measures ANOVA using a mixed model (SAS v9.2). The random effect of our model was subject, the between-subjects effect was treatment group, and the within-subject effect was test day. We analyzed the group effect and the group-by-day 
interaction. We used Tukey's tests to separate means of ANOVA interactions $(\alpha=0.05)$.

\subsection{Residue analysis}

We used reversed-phase, high performance liquid chromatography (HPLC) with ultraviolet detection to quantify anthraquinone residues (i.e., actual concentrations; Table 1) in methods which have been reported previously by Carlson et al. (2013).

\section{Results}

\subsection{Blueberries}

Repellency was not related to tested concentrations of anthraquinone $\left(r^{2}=0.31, P=0.33\right)$. Maximum observed repellency was only $27 \%$ at the targeted concentration of $0.5 \%$ anthraquinone (Fig. 1A). Thus, tested concentrations of anthraquinone did not effectively repel European starlings from treated blueberries during our concentration-response experiment.

Starlings preferred untreated blueberries throughout the preference test $\left(F_{1,9}=22.93, P=0.001\right.$; Fig. $\left.1 \mathrm{~B}\right)$. We observed no
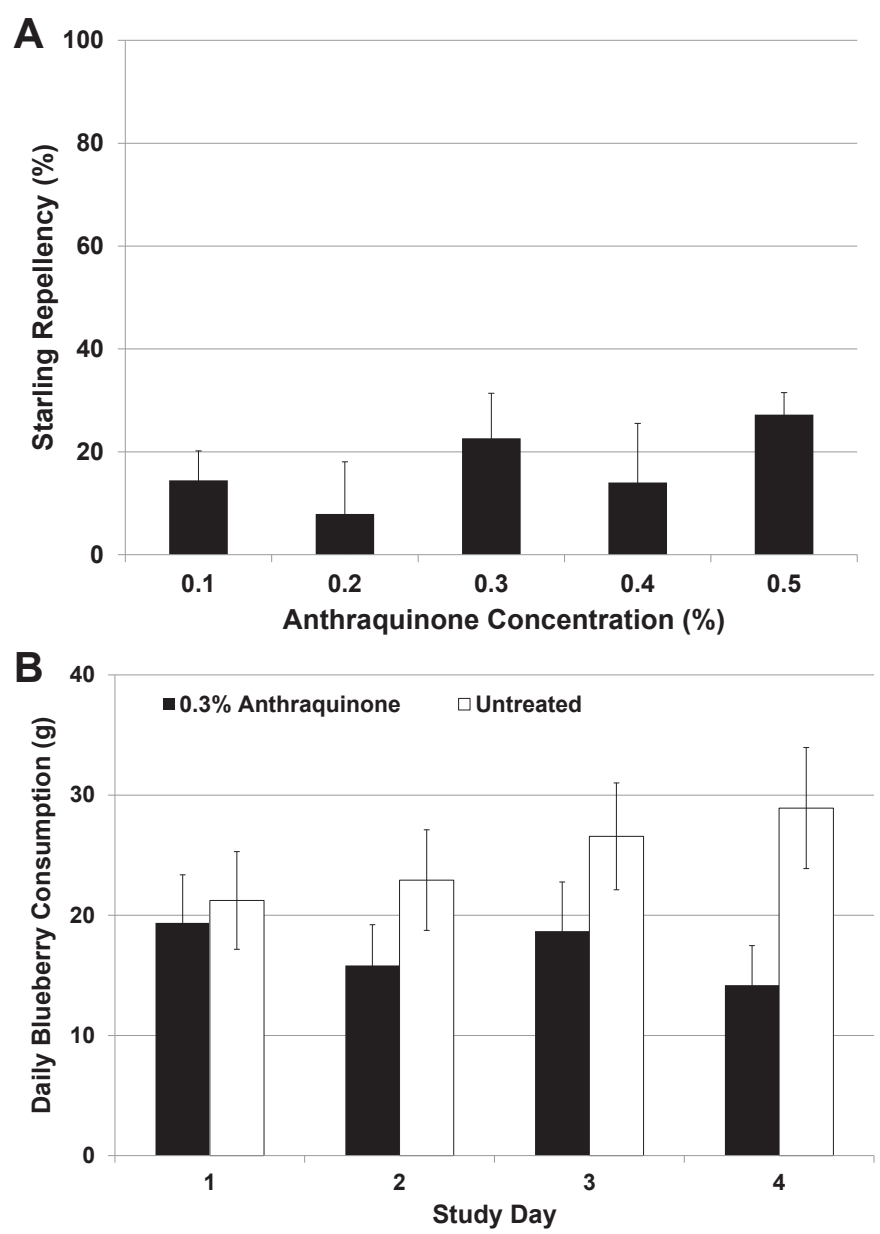

Fig. 1. A. Repellency (mean \pm SE) among 5 targeted concentrations of anthraquinone (Arkion Life Sciences, New Castle, Delaware, USA; $n=10$ individually-caged European starlings/concentration) at the National Wildlife Research Center in Fort Collins, Colorado, USA. Repellency represents test consumption relative to average, pretreatment blueberry consumption. B. Blueberry consumption (mean \pm SE) among European starlings ( $n=10$ individually-caged birds) offered untreated blueberries and blueberries treated with a targeted concentration of $0.3 \%$ anthraquinone (Arkion Life Sciences, New Castle, Delaware, USA) at the National Wildlife Research Center in Fort Collins, Colorado, USA.

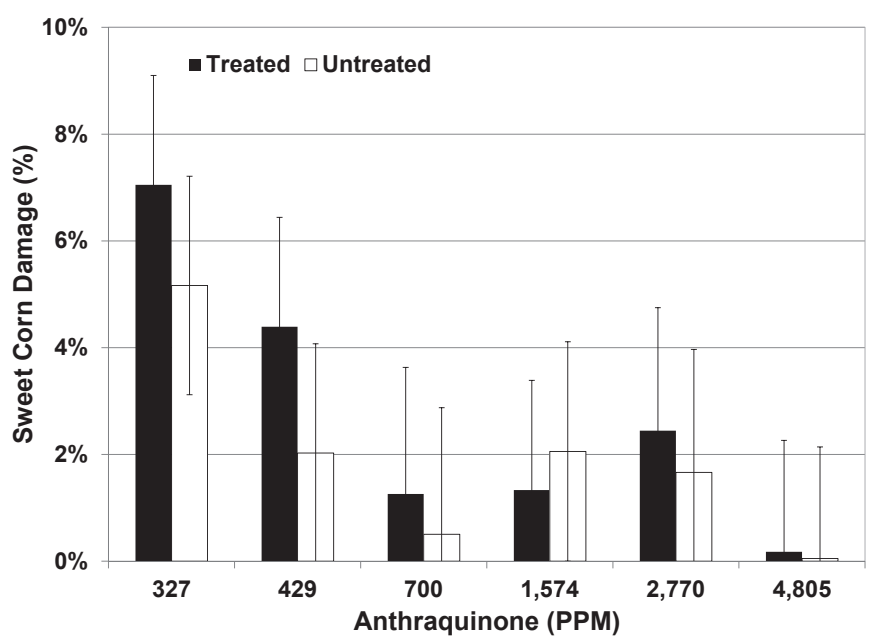

Fig. 2. Percent of kernels damaged from anthraquinone treated and untreated ears of sweet corn exposed to European starlings. Cage testing occurred in Fort Collins, CO USA.
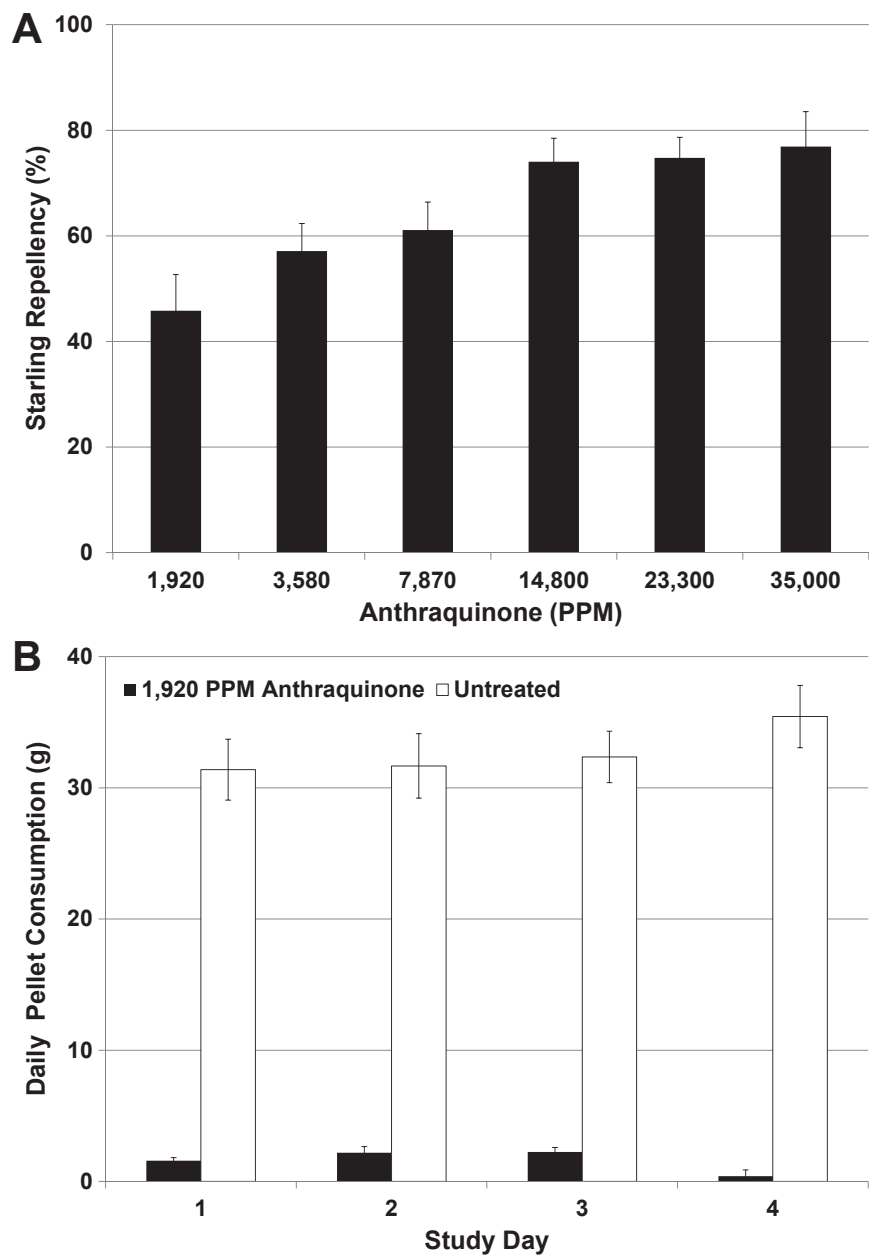

Fig. 3. A. Repellency (mean \pm SE) among 6 targeted concentrations of anthraquinone (Arkion Life Sciences, New Castle, Delaware, USA; $n=9$ individually-caged European starlings/concentration) at the National Wildlife Research Center in Fort Collins, Colorado, USA. Repellency represents test consumption relative to average, pretreatment pellet consumption. B. Pellet consumption (mean \pm SE) among individually caged European starlings $(n=11)$ offered untreated pellets and pellets treated with a targeted concentration of $0.3 \%$ anthraquinone (Arkion Life Sciences, New Castle, Delaware, USA) at the National Wildlife Research Center in Fort Collins, Colorado, USA. 
treatment-by-day interaction during the preference test $\left(F_{6,54}=1.65, P=0.150\right)$. Starlings consumed an average of 17.0 $( \pm 1.8) \mathrm{g}$ of blueberries treated with $0.3 \%$ anthraquinone (targeted concentration) and $24.9( \pm 2.2) \mathrm{g}$ of untreated blueberries per day during the 4-day preference test.

\subsection{Sweet corn}

Percent damage by European starlings was not significantly different between treated and untreated ears $\left(F_{1,65}=1.00, P=0.32\right)$. European starlings consumed an average of $2.1 \% \pm 0.9 \%$ of kernels from untreated ears and $2.8 \% \pm 1.1 \%$ from treated ears during the four day experiment (Fig. 2). The interaction of anthraquinone concentration by corn treatment group was not significantly associated with percent damage, suggesting starling damage was not associated with the concentration of anthraquinone applied to ears of sweet corn. There was no statistical difference in corn damage as concentration level increased $\left(F_{5,60}=1.25, P=0.30\right)$.

\section{3. $16 \%$ Poultry Layer Complete}

We observed a positive concentration-response relationship among tested concentrations of anthraquinone in test pellets $\left(r^{2}=0.95, P=0.001\right)$. However, starlings did not exhibit $\geq 80 \%$ repellency for test pellets containing $35,000 \mathrm{ppm}$ anthraquinone (4.0\% anthraquinone targeted concentration); maximum observed repellency was $77 \%$ (Fig. 3A).

Starlings preferred untreated test pellets throughout the preference test $\left(F_{1,10}=1130.84, P<0.001\right)$. We observed no treatmentby-day interaction during the preference test $\left(F_{6,60}=1.23, P=0.31\right)$. Starlings consumed an average of $1.6( \pm 0.2) \mathrm{g}$ of test pellets containing $1920 \mathrm{ppm}$ anthraquinone $(0.25 \%$ anthraquinone targeted concentration) and $32.7( \pm 2.2) \mathrm{g}$ of untreated test pellets per day during the 4-day preference test (Fig. 3B).

\subsection{CU Bird Carrier}

We observed a positive concentration-response relationship among tested concentrations of anthraquinone on CUBC $\left(r^{2}=0.99\right.$, $P=0.004$; Fig. 4). Starlings exhibited $78 \%$ repellency for CUBC containing 5130 ppm anthraquinone $(0.5 \%$ anthraquinone targeted

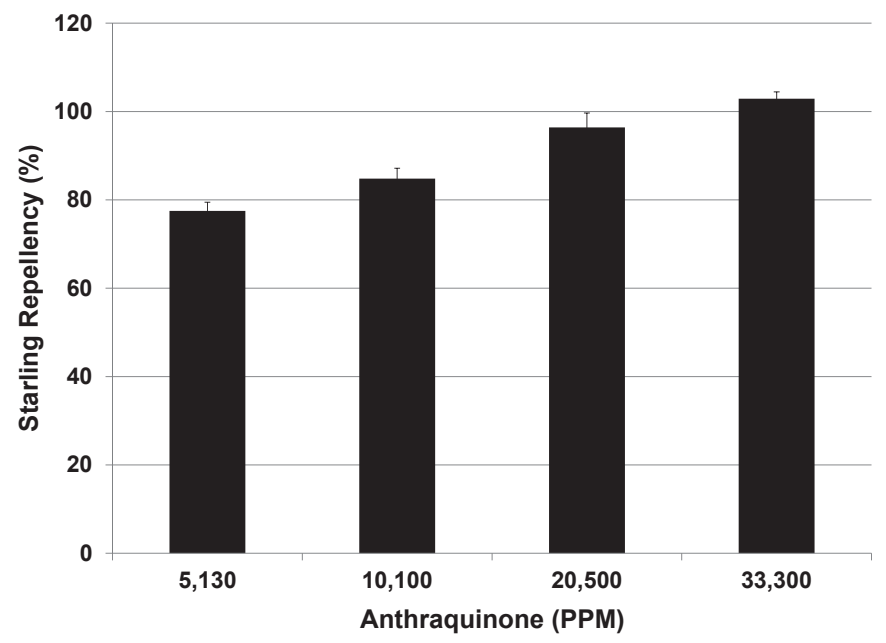

Fig. 4. Repellency (mean \pm SE) among 4 targeted concentrations of anthraquinone (Arkion Life Sciences, New Castle, Delaware, USA; $n=11$ individually-caged European starlings/concentration) at the National Wildlife Research Center in Fort Collins, Colorado, USA. Repellency represents test consumption relative to average, pretreatment CU Bird Carrier consumption. concentration). Maximum repellency was $103 \%$ for CUBC containing 33,300 ppm anthraquinone (4.0\% anthraquinone targeted concentration). Starling repellency $(y)$ was a function of anthraquinone concentration $(x): y=13.704 \operatorname{Ln}(x)-39.787$. We therefore predicted a threshold concentration of $6275 \mathrm{ppm}$ anthraquinone (i.e $80 \%$ repellency), or $104.6 \pm 22.4 \mathrm{mg}$ anthraquinone $\times \mathrm{kg}$ body mass ${ }^{-1}$ for European starlings offered treated CUBC. Thus, tested concentrations of anthraquinone effectively repelled European starlings from anthraquinone-treated CUBC during our concentration-response experiment.

\subsection{SucraShield}

Repellency was inversely related to tested concentrations of SucraShield $\left(r^{2}=0.79, P=0.04\right)$. Maximum observed repellency was $21 \%$ at the lowest targeted concentration of $0.25 \%$ SucraShield (Fig. 5A). Repellency decreased as concentration of SucraShield increased. Thus, tested concentrations of SucraShield did not effectively repel European starlings from treated CUBC during our concentration--response experiment.
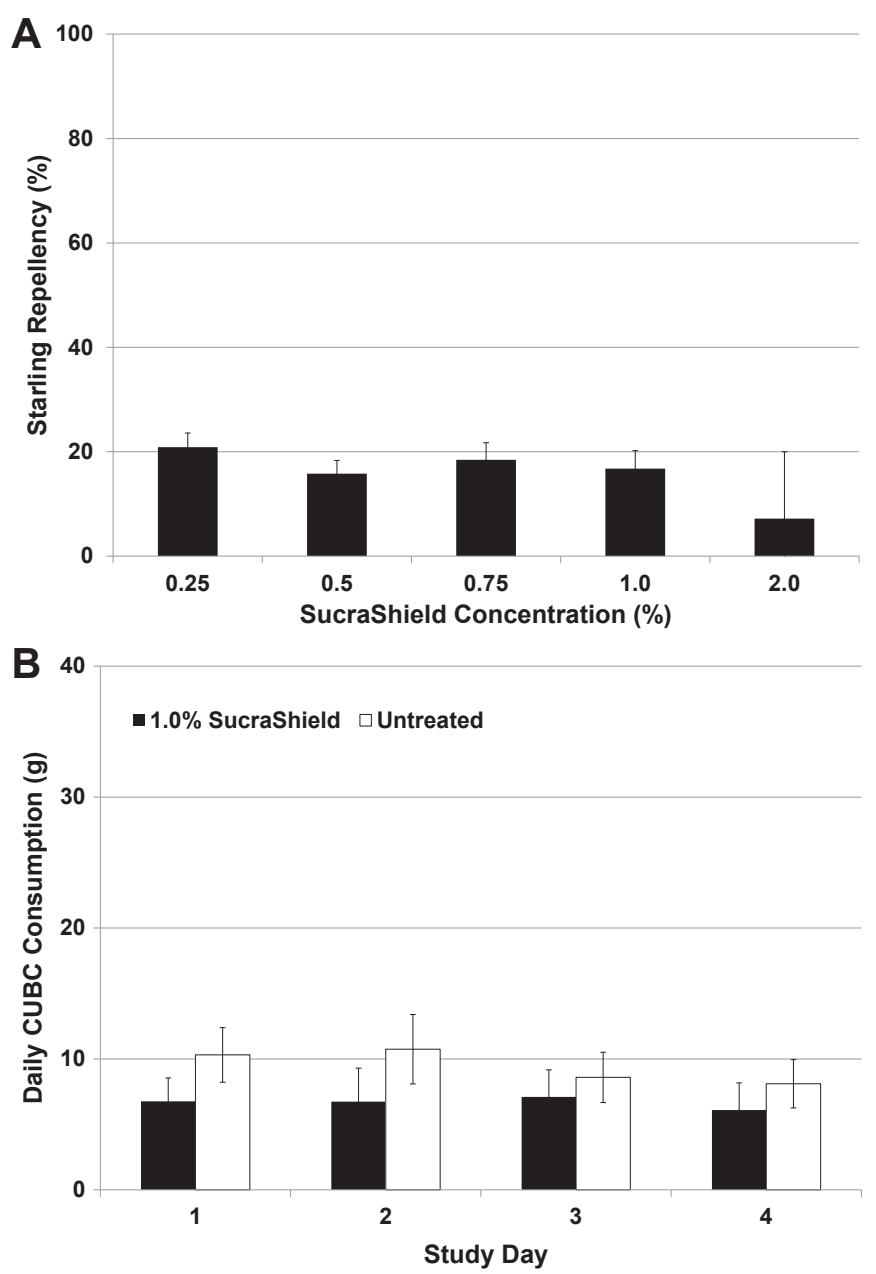

Fig. 5. A. Repellency (mean \pm SE) among 5 targeted concentrations of SucraShield ${ }^{\mathrm{TM}}$ (Natural Forces, Davidson, North Carolina, USA; $n=11$ individually-caged European starlings/concentration) at the National Wildlife Research Center in Fort Collins, Colorado, USA. Repellency represents test consumption relative to average, pretreatment CU Bird Carrier consumption. B. CU Bird Carrier consumption (mean $\pm \mathrm{SE}$ ) among European starlings ( $n=11$ individually-caged birds) offered untreated CU Bird Carrier and CU Bird Carrier treated with a targeted concentration of $1.0 \%$ SucraShield $^{\mathrm{TM}}$ (Natural Forces, Davidson, North Carolina, USA) at the National Wildlife Research Center in Fort Collins, Colorado, USA. 
There was no difference in preference between CUBC treated with SucraShield and untreated CUBC $\left(F_{1,10}=2.93, P=0.12\right)$. We observed no treatment-by-day interaction during the preference test $\left(F_{6,60}=0.18, P=0.98\right)$. Starlings consumed an average of 6.7 $( \pm 1.2) \mathrm{g}$ of CUBC treated with $1.0 \%$ SucraShield (targeted concentration) and $9.4( \pm 1.2) \mathrm{g}$ of untreated CUBC per day during the 4day preference test (Fig. $5 \mathrm{~B}$ ).

\section{Discussion}

\subsection{Fruit/sucrose matrix}

Fruit is a documented portion of the natural diet of European starlings, and blueberry depredation by starlings in the United States can be locally severe (Mott and Stone, 1973; Avery et al., 1992). We expected anthraquinone to be effective as a repellent for European starlings based upon previous laboratory and field efficacy tests of anthraquinone-based repellents in red-winged blackbirds, horned larks (Eremophila alpestris L.), common grackles, ring-necked pheasants (Phasianus colchicus L.) and Canada geese (Werner et al., 2009, 2011a). While starlings readily ate blueberries (up to $255 \mathrm{~g} /$ bird per day), the targeted concentration of $0.5 \%$ anthraquinone was not sufficient to decrease consumption of blueberries. Similarly, there was no difference between starling consumption of anthraquinone-treated sweet corn and untreated sweet corn. However, starlings consumed $21.5 \mathrm{~g}$ of blueberries treated with $0.5 \%$ anthraquinone and only $2.8 \%$ of sweet corn (avg. ear weight 70-100 g) with the same level of anthraquinone during testing. Based on the Agricultural Research Services' National Nutrient Database for Standard Reference (release 24) blueberries contain $9.96 \mathrm{~g}$ of sugar per $100 \mathrm{~g}$ with $1 \%$ of that sugar being sucrose, whereas sweet corn contains $6.26 \mathrm{~g}$ sugar per $100 \mathrm{~g}$ with $14.2 \%$ of that sugar being sucrose. Martinez del Rio et al. (1988) showed that starlings lack sucrase, the enzyme needed to hydrolyze sucrose, and Avery et al. (1995) showed that starlings will respond negatively to artificial fruits having $12.8 \%$ sucrose, but starlings show no difference in consumption for solutions below 10\% sucrose (Clark and Mason, 1993). We believe that the inability to digest sucrose may explain the difference in consumption of the two-test fruit diets at similar levels of repellent.

Although anthraquinone concentrations in our fruit experiments were fairly low (maximum of $5000 \mathrm{ppm}$ anthraquinone), we know from previous experiments that red-winged blackbirds exhibited 80\% repellency for sunflower at $1475 \mathrm{ppm}$, and common grackles exhibited $80 \%$ repellency for sunflower at $9200 \mathrm{ppm}$ (Werner et al., 2009, 2010). Thus, interspecific differences exist for efficacious concentrations of anthraquinone-based repellents. Previous experiments have shown that starlings are less susceptible to chemicals than red-winged blackbirds (Schafer, 1972), indicating that starlings may require considerably higher levels of anthraquinone then red-winged blackbirds for repellent efficacy. In previous testing, red-winged blackbirds tested with Avipel ${ }^{\circledR}$ (an anthraquinone-based repellent) and sweet corn showed a positive relationship between anthraquinone concentration and percent damage (Carlson et al., 2013). At 9619 ppm anthraquinone red- winged blackbirds consumed less than $2 \%$ of kernels on treated ears. The anthraquinone was applied to the husk of the corn and residue levels on kernels compared to the husk were orders of magnitude less in red-winged blackbirds (Carlson et al., 2013). The anthraquinone residue levels on the sweet corn in our starling experiment were lower or similar to those reported for the Carlson et al. (2013) red-winged blackbird experiment however, consumption of sweet corn by starlings in our experiment decreased for both treated and untreated groups as anthraquinone concentration increased. Based on previous studies (Clark and Mason, 1993; Avery et al., 1995) it is possible that there is an interaction between the sucrose levels of the sweet corn and the anthraquinone levels that resulted in decreased consumption of both treated and untreated sweet corn.

The results of our fruit experiments led us to evaluate the SucraShield product for efficacy as a chemical repellent for starlings. SucraShield is marketed as a "sugar-based" product, however, it is chemically-unrelated to sucrose. The active ingredients in SucraShield are sucrose octanoate esters, which belong to the chemical family sucrose fatty acid esters (SFAEs) and can be derived from tobacco plants, and wild potato and tomato plants. SFAEs are used as an emulsifier in human food products and as an additive in poultry farming. In our experiments starlings ate more CUBC treated with SucraShield as the concentration increased. Since SFAEs are derived from sugar and fat (derived from vegetable oil or animal fat), it follows that starlings would eat more CUBC as the targeted concentration of SucraShield increased.

\subsection{Animal/plant based matrix}

Starlings also consumed disparate amounts of $16 \%$ Poultry Layer Complete pellets as compared to CUBC during the pre-test of experiments. Previously, authors have indicated that starlings require at least 30\% crude protein (Bateson and Asher, 2010), whereas our starling maintenance diet contained $16 \%$ crude protein and $3.0 \%$ crude fat, and is made from all vegetable matter (Table 2). Starlings maintained on the 16\% Poultry Layer Complete diet have done well with no other protein supplement although they eat $30 \%$ of their body weight daily in pellets. For example, starlings in the poultry pellet experiment ate $35.2 \pm 0.7 \mathrm{~g}$ on average daily, during the 3-day pre-test. CU Bird Carrier has $18 \%$ crude protein and $28 \%$ crude fat and contains animal fat (Table 2). Starlings readily eat CUBC and due to its higher fat content and animal-based ingredients starlings are able to maintain body weight on considerably less feed. On average, starlings in the SucraShield and CUBC anthraquinone experiments ate $16.5 \pm 0.4 \mathrm{~g}$ and $15.5 \pm 0.3 \mathrm{~g}$ respectively, of CUBC daily during the 3-day pre-test. These data corroborate previous studies that showed starlings inefficiently process plant-based feed and therefore have to consume more to meet their daily requirements (Thompson and Grant, 1968; Taitt, 1973; Al-Joborae, 1979).

Our experiment with 16\% Poultry Layer Complete pellets, the standard maintenance diet for starlings, showed that at 35,000 ppm $80 \%$ repellency was not achieved. These test pellets were prepared using technical anthraquinone (powder obtained from Arkion Life Sciences, New Castle, DE, USA) as opposed to the

Table 2

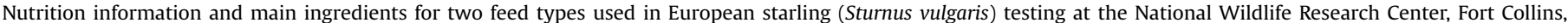
Colorado, USA.

\begin{tabular}{|c|c|c|c|c|}
\hline Feed & Source & Crude protein (\%) & Crude fat (\%) & Crude fiber (\%) \\
\hline $16 \%$ Poultry Layer Complete ${ }^{a}$ & Ranch-Way Fort Collins, CO, USA & 16.0 & 3.0 & 5.5 \\
\hline CU Bird Carrier ${ }^{\mathrm{b}}$ & Purina Mills, Gray Summit, MO, USA & 18.0 & 28.0 & 5.0 \\
\hline
\end{tabular}

\footnotetext{
a $16 \%$ Poultry Layer Complete main ingredients: grain products, plant protein products, roughage products, calcium carbonate, processed grain by-products.
}

b CU Bird Carrier main ingredients: grain products, plant protein products, animal fat preserved with ethoxyquin, glycerol monostearate. 
liquid anthraquinone-based repellent (Arkion Life Sciences, New Castle, DE, USA). Thus the anthraquinone was contained within the pellet. Our experiment using CUBC as the bait matrix showed that starlings exhibited $>80 \%$ repellency at 10,100 ppm anthraquinone and that the threshold concentration for starlings was $6275 \mathrm{ppm}$ anthraquinone. These experiments indicate that the formulation of the test diet (i.e. contained within the pellet vs. topical or surface treatments) affects the efficacy of anthraquinone-based repellents. Similarly, previous studies have shown that Bitrex (a nontoxic, bitter-tasting chemical) is only effective as a deterrent when it is presented externally and its bitter taste is detectable (Skelhorn and Rowe, 2009).

Another factor in the efficacy of anthraquinone as a repellent and the two bait matrices could be related to the ingredients in each matrix and how starlings process these ingredients. Starlings are unable to digest large quantities of cellulose. Although starlings eat plant material, the vegetative component of the starling diet consists of fruits and seeds which have readily digestible carbohydrates (Feare, 1984). Al-Joborae (1979) showed that starlings change their intestine length to better accommodate digestion of plant foods but could not show an increase in digestive efficiency. This leads us to believe that starlings more readily process animal fat and therefore may absorb more anthraquinone when it is presented on CUBC. Conversely, starlings do not readily process plant protein or plant fat and therefore may absorb less anthraquinone when it is presented within pellets. Due to the confounding factor of anthraquinone being within pellets versus on the surface of the CUBC we recommend supplemental laboratory and field efficacy testing to evaluate this theory.

\section{Acknowledgments}

We thank A. Mangan, and three anonymous reviewers for their thoughtful comments on previous versions of our manuscript. We also thank the analytical chemistry unit at the National Wildlife Research Center (Fort Collins, CO, U.S.A.) and Arkion Life Sciences (New Castle, DE, USA) for performing anthraquinone residue analyses. Arkion Life Sciences provided the anthraquinone-based repellent, and Natural Forces LLC (Davidson, NC, USA) provided the SucraShield ${ }^{\mathrm{TM}}$ product for our feeding experiments. Corporate collaborations do not imply endorsement by the United States Department of Agriculture. This project was supported in part by the IR.4 Project, Michigan State University, and the USDA Specialty Crop Research Initiative.

\section{References}

Al-Joborae, F.F., 1979. The Influence of Diet on the Gut Morphology of the Starling (Sturnus vulgaris) (Ph.D. dissertation). Oxford University, Oxford, United Kingdom.

Avery, M.L., 1992. Evaluation of methyl anthranilate as a bird repellent in fruit crops. In: Proc. Vert. Pest Conf. 15, pp. 130-133.

Avery, M.L., Nelson, J.W., Cone, M.A., 1992. Survey of bird damage to blueberries in North America. In: Proc. East. Wildl. Dam. Cont. Conf. 5, pp. 105-110.

Avery, M.L., Decker, D.G., Humphrey, J.S., Hayes, A.A., Laukert, C.C., 1995. Color, size, and location of artificial fruits affect sucrose avoidance by cedar waxwings and European starlings. Auk Ornithol. Adv. 112, 436-444.

Avery, M.L., Humphrey, J.S., Decker, D.G., 1997. Feeding deterrence of anthraquinone, anthracene, and anthrone to rice-eating birds. J. Wildl. Manag. 61, 1359-1365.

Bateson, M., Asher, L., 2010. The European starling. In: Hubrecht, R., Kirkwood, J. (Eds.), The UFAW Handbook on the Care and Management of Laboratory and Other Research Animals, eighth ed. Wiley-Blackwell, Oxford, UK, pp. 697-705.
Bentz, T., Lapidge, S., Dall, D., Sinclair, R.G., 2007. Managing starlings in Australia-can DRC-1339 be the answer? In: Witmer, G.W., Pitt, W.C., Fagerstone, K.A. (Eds.), Managing Vertebrate Invasive Species; Proceedings of an International Symposium. Fort Collins, Colorado, USA, pp. 361-365.

Blackwell, B.F., Helon, D.A., Dolbeer, R.A., 2001. Repelling sandhill cranes from corn: whole-kernel experiments with captive birds. Crop Prot. 20, 65-68.

Carlson, J.C., Tupper, S.K., Werner, S.J., Pettit, S.E., Santer, M.M., Linz, G.M., 2013 Laboratory efficacy of an anthraquinone-based repellent for reducing bird damage to ripening corn. Appl. Anim. Behav. Sci. 145, 26-31.

Clark, L., Mason, J.R., 1993. Interaction between sensory and postingestional repellents in starlings: methyl anthranilate and sucrose. Ecol. Appl. 3, 262-270.

Dolbeer, R.A., Woronecki, P.P., Stickley Jr., A.R., White, S.B., 1978. Agricultural impact of a winter population of blackbirds and starlings. Wilson Bull. 90, 31-44.

Eglington, S.M., Pearce-Higgins, J.W., 2012. Disentangling the relative importance of changes in climate and land-use intensity in driving recent bird population trends. PLoS One 7, e30407.

Feare, C., 1984. The Starling. Oxford University Press, Great Britain, 283 pp.

Feare, C., 1992. The starling in Europe: multiple approaches to a problem species. In: Proc. Vert. Pest Conf. 15, pp. 83-88.

Fischl, J., Caccamise, D.F., 1987. Relationships of diet and roosting behavior in the European starling. Am. Midl. Nat. 117, 395-404.

Freeman, S.N., Robinson, R.A., Clark, J.A., Griffin, B.M., Adams, S.Y., 2007. Changing demography and population decline in the common starling (Sturnus vulgaris): a multisite approach to integrated population monitoring. Ibis 149, 587-596.

Glahn, J.F., Otis, D.L., 1986. Factors influencing blackbird and European starling damage at livestock feeding operations. J. Wildl. Manag. 50, 15-19.

Klosterman, M., Linz, G.M., Slowik, A.A., Homan, H.J., 2013. Comparisons between blackbird damage to corn and sunflower in North Dakota. Crop Prot. 53, 1-5.

Martinez del Rio, C., 1990. Dietary, phylogenetic, and ecological correlates of intestinal sucrose and maltase activity in birds. Physiol. Zool. 63, 987-1011.

Martinez del Rio, C., Stevens, B.R., Daneke, D.E., Andreadis, P.T., 1988. Physiological correlates of preference and aversion for sugars in three species of birds. Physiol. Zool. 61, 222-229.

Mason, J.R., Glahn, J.F., Dolbeer, R.A., Reidinger Jr., R.F., 1985. Field evaluation of dimethyl anthranilate as a bird repellent livestock feed additive. J. Wildl. Manag. 49, 636-642.

Meserve, P.L., 1977. Food habits of a white-tailed kite population in Central Chile Condor Ornithol. Appl. 79, 263-265.

Mott, D.F., Stone, C.P., 1973. Bird Damage to Blueberries in the United States. Bureau of Sport Fisheries and Wildlife Special Scientific Report Wildlife No. 172. Washington D.C.

Poche, R.M., 1998. Development of a new bird repellent, Flight Control. In: Proc Vetebr. Pest Conf., vol. 18, pp. 338-344.

Schafer, E.W., 1972. The acute oral toxicity of 369 pesticidal, pharmaceutical and other chemicals to wild birds. Toxicol. Appl. Pharmacol. 21, 315-330.

Shwiff, S.A., Carlson, J.C., Glass, J.H., Suckow, J., Lowney, M.S., Moxcey, K.M. Larson, B., Linz, G.M., 2012. Producer survey of bird-livestock interactions in commercial dairies. J. Dairy Sci. 95, 6820-6829.

Skelhorn, J., Rowe, C., 2009. Distastefulness as an antipredator defence strategy. Anim. Behav. 78, 761-766.

Stickley, A.R., Dolbeer, R.A., White, S.B., 1976. Starling damage to sprouting wheat in Tennessee. In: Bird Cont. Sem. Proc. 7, pp. 30-38.

Summers, R.W., 1985. The effect of scarers on the presence of starlings (Sturnus vulgaris) in cherry orchards. Crop Prot. 4, 520-528.

Taitt, M.J., 1973. Winter food and feeding requirements of the starling. Bird Study 20, 226-236.

Thompson, R.D., Grant, C.V., 1968. Nutritive value of two laboratory diets for starlings. Lab. Anim. Care 18, 75-79.

Werner, S.J., Carlson, J.C., Tupper, S.K., Santer, M.M., Linz, G.M., 2009. Threshold concentrations of an anthraquinone-based repellent for Canada geese, redwinged blackbirds, and ring-necked pheasants. Appl. Anim. Behav. Sci. 121, 190-196.

Werner, S.J., Linz, G.M., Tupper, S.K., Carlson, J.C., 2010. Laboratory efficacy of chemical repellents for reducing blackbird damage in rice and sunflower crops. J. Wildl. Manag. 74, 1400-1404.

Werner, S.J., Tupper, S.K., Pettit, S.E., Carlson, J.C., Linz, G.M., 2011a. Anthraquinonebased bird repellent for sunflower crops. Appl. Anim. Behav. Sci. 129, 162-169.

Werner, S.J., Tupper, S.K., Pettit, S.E., Carlson, J.C., Linz, G.M., 2011b. Anthraquinone repellent to reduce non-target take of wild birds from zinc phosphide rodenticide applications. Appl. Anim. Behav. Sci. 135, 146-153.

Woronecki, P.P., Dolbeer, R.A., Otis, D.L., 1988. Evaluating corn varieties for resistance to damage by blackbirds and starlings. In: Shumake, S.A., Bullard, R.W. (Eds.) Vertebrate Pest Control and Management Materials: $5^{\text {th }}$ Volume, ASTM STP 974. American Society for Testing and Materials, Philadelphia, 1987, pp. 27-38.

Wright, E.N., 1982. Bird problems and their solutions in Britain. In: Proc. Vert. Pest Conf. 10, pp. 187-189. 